\title{
Fusarium Species from the Cassava Root Rot Complex in West Africa
}

\author{
Ranajit Bandyopadhyay, Maina Mwangi, Sylvester O. Aigbe, and John F. Leslie
}

First, second, and third authors: International Institute of Tropical Agriculture (IITA), PMB 5320, Ibadan, Nigeria; and fourth author: Department of Plant Pathology, Kansas State University, Manhattan 66506. Accepted for publication 28 November 2005.

\begin{abstract}
Bandyopadhyay, R., Mwangi, M., Aigbe, S. O., and Leslie, J. F. 2006. Fusarium species from the cassava root rot complex in West Africa. Phytopathology 96:673-676.

Fusarium species are a significant component of the set of fungi associated with cassava root rot. Yield losses due to root rot average 0.5 to 1 ton/ha but losses $>3$ ton/ha, an equivalent of 15 to $20 \%$ yield, often occur. This paper reviews previous work on cassava root rot and summarizes a few recent studies on Fusarium species associated with the disease. Our studies in Cameroon showed that $30 \%$ of rotted tubers were infected by Fusarium spp. 12 months after planting and represented 25\% of all the fungal isolates recovered. Other commonly recovered fungi were Botryodiplodia theobromae and Armillaria spp. Numerous and diverse species of Fusarium were associated with rotted cassava roots in

Nigeria and Cameroon. At least 13 distinct amplified fragment length polymorphism (AFLP) groups of Fusarium were distinguishable, each group probably a distinct species, and many of them might represent previously undescribed Fusarium species. The two largest of the AFLP groups correspond to $F$. oxysporum and $F$. solani species complex. The distribution of Fusarium spp. varied among countries and among locations within a country, suggesting that germ plasm resistant at one location may not be resistant at another. Fusarium spp. also cause seedling blight of cassava and can be recovered from the stems of infected plants up to $1 \mathrm{~m}$ above the ground. Therefore, the pathogen can spread with stems cut as planting material. Fusarium spp. also can colonize Chromolaena odorata, the dominant weed in short fallows, which could further complicate management efforts by serving as an alternative host for strains that colonize cassava.
\end{abstract}

Cassava, Manihot esculenta Crantz, is a root crop grown widely in tropical and subtropical areas mainly for its starchy tuberous roots, which provide an important source of inexpensive calories, although in some countries the leaves and tender shoots also are eaten as vegetables (4). Traditionally cassava has been grown as part of a subsistence agricultural system, but in recent years the crop has attracted attention as a potential source of income for poor and marginal farmers in Africa (6). Cassava can be utilized industrially as a raw material for the production of confectionaries, ethanol and starch, and in animal feed industries (8). In Africa, the sale of cassava generates cash income for more households than does the sale of any other crop (6). Cassava also provides more than one-half of the dietary calories and other nutrients for over 200 million people in sub-Saharan Africa $(6,7)$. Crop yields are stable, even during droughts, and the plants tolerate low soil fertility and low intensity management.

The tuberous roots of cassava are the part of the plant that usually is eaten. These roots have a short shelf life after harvest and must be processed for food within a day or two after harvest. In some cases, the tuberous roots can remain in the ground after plant maturity to be harvested only as required for consumption (24). Such in-ground storage and delayed harvest is problematic whenever the incidence of root rot is high.

Cassava production is hampered by many factors among which diseases such as cassava mosaic disease (African cassava mosaic virus), bacterial blight (Xanthomonas axonopodis pv. manihotis), anthracnose (Colletotrichum gloeosporioides), and root rots are

Corresponding author: R. Bandyopadhyay

E-mail address: r.bandyopadhyay@ cgiar.org

DOI: 10.1094/PHYTO-96-0673

(C) 2006 The American Phytopathological Society important. Numerous insect/arthropod pests have posed serious challenges in the past and many persist to date (6).

Of the major diseases of cassava, root rots are the most poorly understood and among the least studied. Earlier reports (13) highlighted the importance of root rots as constraints to cassava production, but more recent reviews $(6,9)$ ranked root rots behind mosaic disease and bacterial blight infections. Since rot diseases occur underground where they are not visible, their impact is not as readily perceived as are those caused by foliar pathogens. Cassava plants are quite resilient and have an extensive root system that enables the plant to remain standing and asymptomatic even when heavily infected (18), which further masks the effect of root rotting pathogens until the tubers are harvested. Based on surveys of farmers in the humid forest area of Cameroon, $58 \%$ of the sampled population $(n=120)$ ranked root rot disease as the main constraint to cassava production (M. Mwangi, R. Bandyopadhyay, and C. Nolte, unpublished data). The few field surveys of cassava root rot diseases document the potential pathogens present, but have little information on the yield losses attributable to the various pathogens $(19,23)$. Yield losses of up to $25 \%$ were documented in Cameroon (17), and average yield losses of 0.5 to 1 ton/ha $(\approx 10 \%)$ occurred in a recently concluded trial (M. Mwangi, R. Bandyopadhyay, and J. Gockowski, unpublished data). These losses increased in some fields to 3 ton/ha (nearly 15 to $20 \%$ yield loss), especially if harvesting was delayed during the wet season.

Root rots can occur on young or old cassava plants and can be caused by members of one or several fungal genera. Disease incidence usually is higher during the rainy season, but some pathogens, e.g., Macrophomina phaseolina, are more common during the dry season (18). The main symptom of rot disease is a breakdown in tissue of the mature tuberous roots, usually associated with a foul odor and changes in color, which may be useful in distinguishing the pathogens involved. For example, storage 
tissue of tuberous roots primarily infected by a Fusarium species often are pink or yellow, whereas tissue infected with Botryodiplodia theobromae often is a dark blue or grayish black (1). Infected young feeder roots lose vitality and may desiccate, whereas infected shoots wilt either partially or completely and may lodge. In some cases, fungal structures such as mycelia, sclerotia, rhizomorphs, or pycnidia are seen attached to the infected plant parts (23). Root rots generally are classified into dry or soft rots depending on symptom expression and on their prevalence during either the dry season or the wet season $(15,20)$. Soft rots are common if the soil is wet and/or temperatures lower (27), and in heavy, poorly drained soils with high organic matter content.

Hillocks and Wydra (9) listed the organisms known to cause root rot or to be involved in the root rot complex. In Africa, reports of specific studies on cassava root rots have been published from the Democratic Republic of Congo (DRC) $(16,21)$, Nigeria $(18,19,23)$, Cameroon (17), and Togo (3). In DRC, Pythium species, Fusarium species, and Spherostibe repens occur widely, whereas in Nigeria and Togo, B. theobromae was reported as the dominant pathogen closely followed by Fusarium species. In Benin and in parts of Nigeria, Nattrassia mangiferae is reported to be the most important pathogen (18). From these reports, it is not possible to determine which genus is most important economically, but there is general agreement that Fusarium species are an important component of the fungal complex that causes cassava root rot everywhere that cassava is cultivated.

Fusarium species in the cassava rot complex. Fusarium species isolated from rotted cassava in Africa include $F$. moniliforme sensu lato, $F$. semitectum, $F$. oxysporum, and $F$. solani $(9$ and references therein). $F$. solani and $F$. oxysporum species complex also have been reported as pathogens of cassava in Colombia (14). In a survey conducted in Nigeria in 1998 and 1999, the most frequently isolated pathogen was $B$. theobromae at $75 \%$ frequency, while $F$. solani and $F$. oxysporum together were isolated at a frequency of $45 \%$ (23). In another survey conducted during the dry season in $1996, B$. theobromae was isolated at a frequency of $28 \%$ in Nigeria and at $7.7 \%$ in Benin, while Fusarium species were isolated at a frequency of 13 and $12 \%$ in Nigeria and Benin, respectively (19). In a subsequent survey in Benin during the rainy season in 1997, the isolation frequency of Fusarium species was comparatively higher (23 to $32 \%$ ) than reported before (19).

According to Msikita et al. (18), the most frequently isolated pathogen during the dry season was $N$. mangiferae, recovered at frequencies of 41 and $56 \%$ in Nigeria and Benin, respectively, but these values were not similar to those reported by Onyeka (23) or found in subsequent surveys that we carried out. However, there is concurrence that $N$. mangiferae is adapted to diverse ecological conditions and that it can thrive well even in areas with $<1,000 \mathrm{~mm}$ of rainfall per year, whereas B. theobromae, $F$. solani, and $F$. oxysporum are more frequent in areas with $>1,600 \mathrm{~mm}$ of rainfall per year.

From our recently concluded studies in Cameroon, the frequency of isolation of Fusarium species from infected feeder roots and rotted tuberous roots at 6,9 , and 12 months after planting (MAP) was $\approx 25$ and $\approx 30 \%$ of the isolated fungi at different stages of plant growth (M. Mwangi, C. Nolte, R. Bandyopadhyay, and M. Tindo, unpublished data). Of the seven fungal taxa that we isolated in Cameroon, B. theobromae was second only to $\mathrm{Fu}$ sarium and followed in frequency by Trichoderma and Armillaria. The frequency at which we recovered Fusarium species in Cameroon was similar to that of the 23 to $32 \%$ frequency reported during the rainy season in Benin (18) and was below the $45 \%$ frequency reported for Nigeria (23). The frequency of isolation of $B$. theobromae in our studies in Cameroon (20 to 26\%) also was similar to that reported in Benin (24 to 28\%) and well below the $75 \%$ frequency reported for Nigeria (23). The differences might result from climatic differences in the areas surveyed as the study by Msikita et al. (19) was done in areas receiving 900 to $1,300 \mathrm{~mm}$ of rainfall per year and that of Onyeka (23) was done in areas receiving 1,600 to $2,800 \mathrm{~mm}$ of rainfall per year.

The consistent recovery of Trichoderma species from rotted roots in Cameroon (>20\%) and Nigeria $(\approx 55 \%)(23)$ is important because members of this genus have not been reported to be pathogenic on cassava and our tests for pathogenicity have so far repeatedly found Trichoderma species to be at most weakly virulent root pathogens. We think that Trichoderma spp. are secondary pathogens that can invade cassava tubers rapidly once a primary pathogen has created an opening. Another pathogen that we isolated frequently in Cameroon but that was rare in other countries other than DRC is Armillaria spp. The low rate of recovery of Armillaria spp. could be due to the fact that it grows slowly and rather poorly on potato dextrose agar, which is commonly used for routine fungal isolations. These fungi are more efficiently recovered on a selective medium (22). This species accounted for 11,15 , and $20 \%$ of all of the fungi we isolated 6,9 , and 12 MAP, respectively.

We have not found $M$. phaseolina to be an important component of the rot fungi complex in the humid forest areas, probably because this pathogen prefers arid environments (18). In general, more fungi occur in the humid forest ecological zone, which is characterized by rainfall averaging 2,000 to $2,400 \mathrm{~mm}$ per year, than occur in the agroecological zones receiving $<1,600 \mathrm{~mm}$ of rainfall per year (25).

As part of our studies on fungal succession in the root rot complex, we designed a trial in which three cassava cultivars (TME1, 30572 , and 4(2)1425) were grown at three locations, and fungi were isolated from the roots and tuberous roots at 3, 6, 9, and 12 MAP. The locations were Ibadan $(1,000$ to $1,300 \mathrm{~mm}$ of rainfall per year), Sabongida (1,600 to $2,100 \mathrm{~mm}$ of rainfall per year), and Onne $(2,100$ to $2,850 \mathrm{~mm}$ of rainfall per year). Other than differences in rainfall, the soil in Onne was more acidic (3.9 compared with 5.8 in Ibadan and Sabongida) and richer in $\mathrm{P}$ (72 cMol/ $\mathrm{kg}$ compared with 8 to $10 \mathrm{cMol} / \mathrm{kg}$ in Ibadan and Sabongida) and clay content (24\% compared with 9.0 to $9.3 \%$ in the other two locations). Soil in Sabongida was high in organic carbon because this site was located in a recently cleared forest. Our unpublished results indicated that Fusarium species were dominant 6, 9, and $12 \mathrm{MAP}$ at Ibadan (67 to $84 \%$ of all isolates). Fusarium species also were recovered at high frequency from Onne at 6 MAP (83\%) and Sabongida at 9 MAP (73\%). Nearly $50 \%$ of the recovered isolates were species of Fusarium at Sabongida 12 MAP but only $16 \%$ at Onne. Based on morphological characters, $F$. solani was more common than $F$. oxysporum and $B$. theobromae at all locations except at Onne. The dominant pathogen at Onne was $B$. theobromae, which accounted for 33 to $65 \%$ of the fungal isolates recovered there, while at Ibadan and Sabongida, B. theobromae accounted for only 7 to $23 \%$ of all the fungi isolated. Our results suggest that Fusarium species dominate in the lower rainfall areas and that $B$. theobromae dominates in high rainfall areas. At 12 MAP, root rot incidence and severity were similar at all three sites, with cv. TME1 the most susceptible and cv. 4(2)1425 the most tolerant.

The Fusarium species recovered from rotted cassava tubers are numerous and diverse. In studies with amplified fragment length polymorphisms (AFLPs), at least 13 distinct groups could be distinguished based on banding patterns. Each of these groups probably represents a distinct species, and many of them lack good matches in the existing DNA databases, suggesting that at least some of these AFLP groups represent previously undescribed Fusarium species. The two largest of the AFLP groups correspond to $F$. oxysporum and $F$. solani. Curiously, the $F$. solani isolates were limited to Nigeria while $F$. oxysporum isolates were found in Nigeria but were much more common in Cameroon. Other AFLP groups also were limited to only one of these countries. Most of the isolates recovered were genetically unique, 
i.e., not identical to any other strain sampled; however, some clones were recovered, some of which were found in more than one site within a country.

Both $F$. oxysporum and $F$. solani species complex are genetically diverse and common in soils worldwide. Their dominance in rotted cassava root tubers means that numerous individual strains need to be evaluated for pathogenicity to determine if pathogenicity is a property of only some of the strains in the population or if it is instead a property of the population as a whole. Parallel analyses of isolates from soils that are not cultivated or that are cultivated for other crops will be needed to determine if crop rotation could help reduce the incidence of the disease. Geographic differences in fungal populations also mean that identifying effective host plant resistance may be challenging and that germ plasm resistant at one location may not be resistant at another.

Cassava tuber rot pathogens in the stem. Although Fusarium infection of cassava stems is easily recognized, only infection by $B$. theobromae has been reported to be widespread on harvested stems from Nigeria, Benin, and Cameroon (9). Infection of stems is more clearly noticeable during the wet seasons when white fungal structures often are seen at the base of the stem just above the soil level. Usually the infected bark portion is dark and has cracks that extend for several centimeters upward along the stem. To determine how high root rot causing fungi can move in the stems, we harvested cassava stems from naturally infested fields. Stems were cut into $10-\mathrm{cm}$ segments starting at soil level and continuing upward for $1 \mathrm{~m}$. Each $10-\mathrm{cm}$ segment was planted in sterile soil and the health of emerging shoots was evaluated for 7 weeks.

We found that Fusarium species occurred throughout the entire meter of cassava stem. The isolation frequency of Fusarium species was 19 to $31 \%$, and there was no significant difference in $F u$ sarium isolation frequencies based on height above soil level $(P=$ $0.89)$. In comparison, the isolation frequency of $B$. theobromae from infected stem pieces was significantly higher $(P=0.01)$ in the lowest $20-\mathrm{cm}$ portion of the stem than in the higher portions. At 30 to $100 \mathrm{~cm}$ above soil level, B. theobromae was recovered at a frequency of 11 to $21 \%$ compared with 49 and $36 \%$ recovery frequencies for the two lowest stem pieces, respectively. Thus, Fusarium moves and establishes further up the stem than do other fungi causing rots and could be easily disseminated with the cuttings planted for the next season. There was a significant difference in viability between the stem pieces from the lower $20 \mathrm{~cm}$ of the stem and those $>30 \mathrm{~cm}$ above the soil line. Ten to forty percent of the stems from the upper portion of the stem wilted and died within 3 weeks after planting, while 50 to $70 \%$ of the stem pieces from the lower portion of the stem did not survive the first few weeks postemergence. The finding that root rot causing fungi also are found in the stems is significant because cassava has a long vegetative cycle (24), and thus the pathogens have sufficient time to move and establish well in the stems before they are harvested. Establishment of seedlings raised from infected cuttings is significantly reduced, resulting in low and patchy plant stand.

Cassava root rot pathogens and fallow habitat. The regeneration of natural vegetation (fallowing) is a traditional practice for restoring fertility of agricultural land in many parts of the tropics (26). Since interaction between vegetation and soil could influence survival and population dynamics of soilborne pathogens, we evaluated the interaction of Fusarium spp. with Chromolaena odorata (syn. Eupatorium odoratum), a dominant weed in short fallows in humid forest areas. In some countries, $C$. odorata is considered an invasive weed (28), while in others it is considered a beneficial cover crop that can serve as a source of green manure (12) and help suppress other more harmful weeds such as Imperata cylindrica (2). Some reports indicate that roots of $C$. odorata produce chitinases and 1,3 $\beta$-glucanases, which have known antifungal properties (5).
We evaluated the interaction between $C$. odorata, $F$. solani, and $B$. theobromae. Three-week-old plants were grown in sterile soil and inoculated with one of the two fungi. F. solani and $B$. theobromae were reisolated from 18 to $30 \%$ of the roots of the inoculated plants 3 months after inoculation, and $F$. solani was recovered from 6 to $10 \%$ of the plant stems as well. Relative to uninoculated plants, both pathogens significantly reduced shoot biomass of $C$. odorata $(P=0.0008)$, root biomass $(P=0.003)$, and plant height $(P=0.0019)$, but plants were not killed by the pathogens. Growth of $C$. odorata was suppressed more by treatment with $F$. solani than by $B$. theobromae. Thus, $C$. odorata can serve as an alternate host for either of these pathogens. In West and Central Africa, there currently is no agreement on the role of C. odorata in agriculture (28). These results strengthen the case for management programs that reduce the population of the weed such as is being done in Ghana and South Africa.

Other organisms also can enhance cassava root rot diseases. One pest of particular concern is the African root and tuber scale (Stictococcus vayssierei). This pest is a subterranean insect indigenous to the humid forest zone of Central Africa that has increased as a major constraint of cassava production since the mid1970s (11). At high densities the scale by itself can lead to yield losses of 30 to $60 \%$, but in interactions with root rot causing fungi these losses can go even higher (6). Other important pests include nematodes, e.g., Meloidogyne incognita and M. javanica, which also can interact with microbial pathogens in the development of cassava tuber rot complexes (10). Research at the International Institute of Tropical Agriculture (IITA) has found that the presence of root knot nematodes substantially increases the incidence and severity of damage to tuberous roots by B. theobromae (D. Coyne, IITA, Ibadan, personal communication). There are no data on the interaction of these nematodes and the Fusarium spp.

Conclusions. From the review and research outcomes discussed above, it is clear that Fusarium spp. are an important component of the cassava root rot complex. Understanding the interactions amongst the various causal agents associated with this disease complex requires targeted, tightly focused studies to elucidate the roles of individual species in the disease process as well as the nature and extent of their interactions with one another. As yet, there is no conclusive evidence that crop variety influences the constituents of this disease complex, but given the apparent differences attributable to geographic location, this possibility clearly warrants further study. As indicated by the findings with C. odorata and the ability of the fungi involved to colonize cassava stems, the role of alternative hosts and nonpathogenic niches need to be better understood if this disease complex is to be managed effectively.

\section{ACKNOWLEDGMENTS}

We thank A. Beyer, B. van Scoyoc, and G. Ogbe for technical assistance, and the U.S. Agency for International Development for financial support through the IARC-US Institution Linkage Grant. This research was supported in part by the Kansas Agricultural Experiment Station, Manhattan (contribution no. 05-171-J).

\section{LITERATURE CITED}

1. Akinyele, B., and Ikotun, T. 1989. Microorganisms associated with cassava tuber rot. IITA Root and Tuber and Plantain Improvement Program. Pages 16-18 in: IITA 1988 Annual Report. International Institute of Tropical Agriculture, Ibadan, Nigeria.

2. Baxter, J. 1995. Chromolaena odorata. Weed for the killing or shrub for the tilling. Agrofor. Today 7:6-8.

3. Boher, B., Ptcholo, A., and Tchabama, B. 1997. Identification of the factors enhancing the occurrence of an unusual stem and root rot in cassava in Togo. Cultural practices are accused. Cahiers Rech. Develop. 43:52-58.

4. Dahniya, M. T. 1994. An overview of cassava in Africa. Afr. Crop Sci. J. $2: 337-343$ 
5. Dischar, B., Moawad, A. M., and Wolf, G. A. 2002. Microplate colorimetric assay for endo-acting amylase, chitinase and 1,3 $\beta$-glucanase activities in Chromolaena odorata roots colonized with VA mycorrhizal fungi. Page 31 in: Book of Abstracts, Deutscher Tropentag 2002, Germany. www.tropentag.de/2002/pdf/proceedings.pdf

6. Dixon, A. G. O., Bandyopadhyay, R., Coyne, D., Ferguson, M., Ferris, S., Hanna, R., Hughes, J., Ingelbrecht, I., Legg, J., Mahungu, N., Manyong, V., Mowbray, D., Neuenschwander, P., Whyte, J., Hartmann, P., and Ortiz, R. 2003. Cassava: From poor farmers' crop to pacesetter of African rural development. Chronica Hortic. 43:8-15.

7. El-Sharkaway, M. A. 1993. Drought tolerant cassava for Africa, Asia and Latin America. Bioscience 43:441-451.

8. FAO (Food and Agriculture Organization of the United Nations). 2001. The global cassava development strategy and implementation plan. Vol. 1. FAO, Rome.

9. Hillocks, R. J., and Wydra, K. 2002. Bacterial, fungal and nematode diseases. Pages 261-280 in: Cassava: Biology, Production and Utilization. R. J. Hillocks, J. M. Thresh, and A. C. Belloti, eds. CABI, UK.

10. Jatal, P., and Bridge, J. 1990. Nematode parasites of root and tuber crops. Pages 137-180 in: Plant Parasitic Nematodes in Subtropical and Tropical Agriculture. M. Luc, R. A. Sikora, and J. Bridge, eds. CABI, UK.

11. Lema, K. M., Tata-Hangy, K., and Bidiaka, M. 2004. Management of African root and tuber scale using improved cassava genotypes and mineral fertilizers. Afr. Crop Sci. J. 12:217-221.

12. Litzenberger, S. C., and Lip, H. T. 1961. Utilizing Eupatorium odoratum L. to improve crop yields in Cambodia. Agron. J. 53:321-324.

13. Lozano, J. C. 1989. Outbreak of cassava diseases and losses induced. Fitopathol. Brasil. 14:7-11.

14. Lozano, J. C. 1992. Overview of integrated cassava diseases. Fitopathol. Brasil. 17:18-22.

15. Lozano, J. C., and Nolt, B. 1994. Diseases of cassava (Manihot esculenta Crantz). Pages 36-37 in: Common Names for Plant Diseases 1994. The American Phytopathological Society, St. Paul, MN.

16. Makambila, C. 1994. The fungal diseases of cassava in the Republic of Congo, Central Africa. Afr. Crop Sci. J. 2:511-517.

17. Messiga, A. J. N. A., Mwangi, M., Bandyopadhyay, R., and Nolte, C. 2004. The status of fungal tuber rots as a constraint to cassava production in the Pouma district of Cameroon. Page 42 in: Book of Abstracts of the 9th Triennial Symposium of the International Society for Root and Tuber Crops, Mombasa, Kenya.

18. Msikita, W., Bissang, B., James, B. D., Baimey, H., Wilkinson, H. T., Ahounou, M., and Fagbemisi, R. 2005. Prevalence and severity of Nattrassia mangiferae root and stem rot pathogen of cassava in Benin. Plant Dis. 89:12-16.

19. Msikita, W., Yaninek, J. S., Ahounou, M., Baimey, H., and Fagbemisi, R. 1997. First report of Nattrassia mangiferae root and stem rot of cassava in West Africa. Plant Dis. 81:1332.

20. Msikita, W., Yaninek, J. S., Fiolou, M., Baimey, H., and Fagbemisi, R. 1997. Development of a system to screen and select for resistance to Fusarium solani. Afr. J. Root Tuber Crops 2:59-61.

21. Mwangi, M., Bandyopadhyay, R., Dixon, A. G. O., and Tata-Hangy, K. 2004. The status of fungal tuber rots as constraints to cassava production and utilization in eastern Democratic Republic of Congo. Page 41 in: Book of Abstracts of the 9th Triennial Symposium of the International Society for Root and Tuber Crops, Mombasa, Kenya.

22. Mwenje, E., Ride, J. P., and Pearce, R. B. 1998. Distribution of Zimbabwean Armillaria groups and their pathogenicity on cassava. Plant Pathol. 47:623-632.

23. Onyeka, T. J. 2002. Cassava root rot fungi in Nigeria: Variability in Botryodiplodia theobromae isolates and evaluation of cassava germplasm for root rot resistance. Ph.D. thesis. University of Ibadan, Nigeria.

24. Onyeka, T. J., Dixon, A. G. O., and Ekpo, E. J. A. 2005. Assessment of laboratory methods for evaluating cassava genotypes for resistance to root rot disease. Mycopathologia 159:461-467.

25. Salako, F. K., Ghuman, B. S., and Lal, R. 1995. Rainfall erosivity in south-central Nigeria. Soil Tech. 7:279-290.

26. Szotz, L. T., Palm, C. A., and Buresh, R. J. 1999. Ecosystem fertility and fallow function in the humid and subhumid tropics. Agrofor. Sys. 47:163-196.

27. Theberge, R. L. (ed.) 1985. Common African Pests and Diseases of Cassava, Yam, Sweet Potato and Cocoyam. International Institute of Tropical Agriculture, Ibadan, Nigeria.

28. Zachariades, C. 2001. Fifth Chromolaena workshop report. Pest Biocontrol News and Information. Vol. 22, No. 1. Plant Protection Research Institute, South Africa. 